\title{
Fungsi dan Makna Seni Jemblung Murtadho dari Jawa Timur.
}

\section{Harpang Yudha Karyawanto}

Jurusan Sendratasik Fakultas Bahasa dan Seni Universitas Negeri Surabaya

\section{Abstract}

This research examines the problem of the value of Jemblung Murtadho art.The research object is Jemblung's art Sadat Kawedar Murthado in Tunjung village, Udanawu subdistrict, Blitar regency. The purpose of this research are: (1) examine the meaning of art performing of Jemblung Murthado, (2) examine the art function of Jemblung in performances. The research approach is using qualitative approach with ethnomusicology method. Data collection techniques is using: (1) recording techniques, audio and audiovisual, (2) note taking, (3) interviewing, (4) literature study and documentation analysis. The steps in analyzing the data was done by: Data transcription, understanding data, classification, and data condification. While for the validity of data, the researcher (1) doing triangulation, (2) doing peer debriefing, and (3) doing member check and audit trial.The research on music in Jemblung's Murtadho with ethnomusicology approach will be reviewed by the textual and contextual. The textual elements will expose the problems concerning aspects of his music while contextual elements will explain about the culture of the community as a supporter of the arts. The results of this research on forms of art music Jemblung covered all of musikologic aspects, namely: (a) the concept of music in Jemblung's, it has Java's concept of Islamic art music, which is a form of praise songs with the addition of story as a media in religious proselyzing, (b) the form of presentation is divided into two elements among the elements of music and literature, and (c) The means of presentation which includes place, time, players, and costumes. The findings regarding the social function of Jemblung's Murtadho include: (a) as aesthetic satisfaction,(b) as an entertainment, (c) as a means of communication, (d) as a strengthen compliance with social norms, $(e)$ as a validation of social institutions, and religious rituals, $(f)$ as a contribution to the sustainability and stability of culture, (g) as an educational tool for the community, (b) as a community mental forming,(i) as a means of obtaining income and (j) as a Host side traders to sell.

Keywords: The value of art, ethnomusicology, Jemblung Murtadho, meaning, and social function.

\section{PENDAHULUAN}

Seni Jemblung merupakan salah satu bentuk kesenian pertunjukan rakyat tradisional yang hampir sama dengan seni shalawatan. Secara garis besar yang membedakan kesenian ini dengan seni shalawatan adalah adanya penyampaian cerita/lakon dengan media wayang pada bagian pertunjukannya, sedangkan dalam penyajiannya sama-sama menggunakan bahasa Jawa yang isinya merupakan tembang-tembang pujian terhadap keagungan Tuhan Yang Maha Esa dan kepada Junjungan Nabi Muhammad SAW.

Kesenian tersebut dikemas dalam sebuah rangkaian cerita kisah nyata zaman dahulu dan diselingi dengan tembang-tembang Islami tersebut. Sebagai salah satu nilai budaya merupakan satu hal penting untuk diangkat ke dalam karya tulis. Alasannya; karena sepengetahuan penulis meskipun kesenian selawatan sudah pernah ada yang mengangkat ke dalam karya tulis, namun dalam penyajiannya masih menggunakan bahasa Arab, seperti halnya ksesenian selawatan lain yang pernah penulis ketahui. Hal ini sudah barang tentu berbeda dengan yang ada di desa Tunjung, sehingga dengan diangkatnya kesenian Jemblung dapat dijadikan bahan informasi yang berguna bagi ilmu pengetahuan dengan harapan dapat memberikan masukan bagi perkembangan 
bangsa dan negara khususnya dalam bidang usaha pelestarian seni budaya.

Perkembangan seni Jemblung Murtadho dari tahun ke tahun mengalami peningkatan. Hal tersebut dapat dilihat mulai memaraknya berbagai kalangan yang ingin mementaskan Jemblung dalam acara hajatan maupun yang bersifat hiburan, meskipun kesenian ini hampir menurun dalam komunitas kesenian, dan keberadaannya akibat perkembangan zaman. Dalam penyajian seni Jemblung dikemas apik sesuai acara yang akan diselenggarakan oleh konsumen atau orang yang mempunyai hajatan, tanpa mengubah estetika seni asli kesenian tersebut.

Dilihat keberadaannya seni Jemblung mengalami perubahan konsep garap musik yang disebabkan karena perkembangan zaman yang semakin modern, tetapi tidak mengurangi keaslian seni itu sendiri. Hal ini bisa dilihat dalam penyajiannya terdapat tambahan beberapa alat musik tradisi maupun modern, di antaranya saron, demung, peking, gong, keyboard, gitar elektrik dan ketipung.

Seni Jemblung menggunakan alat musik tradisi dan modern. Dapat di lihat dalam penyajiannya dari jenis musik yang melantunkan tembang sebagai transisi dalam setiap pergantian bagian dari sebuah bentuk pertunjukannya. Seni Jemblung di desa Tunjung, Kabupaten Blitar yang asli menggunakan instrumen yang terbuat dari kayu dan kulit hewan. Akan tetapi akibat berjalannya waktu, serta ada permintaan dari konsumen, ditambah sebagian instrumen gamelan dan alat musik modern yang lain seperti yang disebut di atas.

Di dalam penyajiannya, masing-masing instrumen mempunyai ukuran yang berbedabeda, serta mempunyai wilayah bunyi yang berlainan, seperti yang pernah diketahui tentang karakteristik alat musik gamelan. Instrumen yang terbuat dari kayu dan kulit tersebut di antaranya, terbang, kentrung, kempling, kendang, Jidor, sedangkan bagian instrumen gamelan tersebut ialah saron, demung, kempul, dan gong, serta alat musik modern yaitu keyboard dan gitar elektrik sebagai pelengkap untuk memenuhi kebutuhan yang belum .

Seni Jemblung merupakan salah satu bentuk kesenian pertunjukan rakyat tradisional yang hidup dan berkembang dalam masyarakat yang mempunyai banyak fungsi dalam setiap pertunjukanya. Antara lain merupakan sarana dalam mengajarkan kepada masyarakat dalam menjalankan kehidupannya sehari-hari. Disamping itu melalui cerita/lakon yang dipentaskan masyarakat dapat mengambil atau memetik hikmah dari makna cerita tersebut, sehingga masyarakat termotivasi dan tergugah untuk melakukan hal yang lebih baik dalam kehidupannya, karena pada dasarnya manusia selalu berkembang untuk berusaha memperbaiki kesejahteraan hidupnya. Selain itu manusia juga belajar menentukan perilaku berdasarkan kognisi dan lingkungan sosial.

Adapun fungsi seni Jemblung dalam pertunjukannya adalah menjadi jembatan untuk memberi dorongan atau motivasi kepada masyarakat untuk berpartisipasi dalam 
pembangunan desa melalui nilai-nilai yang disampaikan melalui ceritanya, khususnya nilai yang dapat membentuk mental masyarakat sesuai dengan kaidah ajaran islam. Seni Jemblung pada hakekatnya merupakan suatu tindakan komunikasi, serta media pendidikan non formal bagi masyarakat penikmat kesenian.

Permasalahan yang menarik untuk dikaji dan dijadikan bahan penelitian ini adalah (1) Bagaimana makna seni Jemblung Murtadho (2) Bagaimana fungsi seni Jemblung dalam pertunjukannya.

\section{METODE PENELITIAN}

Kata kualitatif menyiratkan penekanan pada proses dan makna yang tidak dikaji secara ketat atau belum diukur (jika memang diukur) dari sisi kuantitas, jumlah, intensitas, atau frekuensinya. Para peneliti kualitatif menekankan sifat realita yang terbangun secara sosial hubungan erat antara peneliti dengan subjek yang diteliti, dan tekanan situasi yang membentuk penyelidikan. Para peneliti semacam ini mementingkan sifat penyelidikan yang syaratnilai. Mereka mencari jawaban atas pertanyaanpertanyaan yang menyoroti cara munculnya pengalaman sosial sekaligus perolehan maknanya. Sebaliknya, penelitian kuantitatis menitikberatkan pengukuran dan analisis hubungan sebab-akibat antara bermacammacam variabel, bukan prosesnya. Penyelidikan dipandang berada dalam kerangka bebas nilai (Denzin, 2009:6).

Berdasarkan sifat data yang akan dianalisis, penelitian ini menggunakan disain penelitian kualitatif yang akan menerangkan segala sesuatu dengan apa adanya dan nyata, kemudian akan dianalisis dengan pendekatan etnomusikologis.

Pendekatan merupakan ruang lingkup penelitian, berhubungan dengan aspek-aspek yang akan diungkap dalam penelitian. Pendekatan akan membingkai objek apa saja yang mungkin diungkap dalam penelitian. Itulah sebabnya pendekatan juga sering dinamakan motode penelitian. Metode penelitian adalah cara yang dipilih peneliti dengan mempertimbangkan bentuk, isi, dan sifat sastra sebagai subjek kajian. Metode semestinya mengangkat cara yang operasional dalam penelitian. Metode ini membutuhkan langkah penelitian yang pantas diikuti. Adapun teknis berhubungan dengan proses pengambilan data dan analisis penelitian (Endraswara, 2003:8).

Ciri penelitian kualitatif adalah (1) latar alamiah, (2) manusia sebagai alat (instrumen), (3) metode berupa: pengamatan, wawancara, dan penelaahan dokumen, (4) analisis data secara induktif, (5) teori dari dasar (grounded theory), (6) deskriptif (berupa kata-kata, gambar), (7) lebih mementingkan proses daripada hasil, (8) batasan penelitian ditentukan oleh fokus, (9) keabsahan data dilakukan dengan: triangulasi, peer debriefing, dan member check, (10) desain yang bersifat sementara (menyusun desain secara terusmenerus disesuaikan dengan kenyataan di lapangan).

Penulisan karya tulis ini menggunakan metode deskriptif analisis. Metode deskriptif dapat dilakukan pencandraan secara sistematis, 
faktual dan akurat mengenai fakta-fakta serta sifat-sifat populasi atau daerah.

Usaha mendiskripsikan fakta-fakta ini tahap permulaan tertuju pada usaha mengemukakan gejala-gejala secara lengkap di dalam aspek yang diselidiki, agar lebih jelas keadaan atau kondisinya. Oleh karena itu pada tahap ini metode deskriptif tidak lebih dari pada penelitian yang bersifat fakta-fakta seadanya (fact finding). Deskriptif juga bisa dimaksudkan untuk membeberkan suatu kajian secara rinci dan jelas dengan disertai argumentasi atau pembuktian. Analisis dimaksudkan untuk menguraikan atau mengadakan penyelidikan terhadap suatu peristiwa untuk mengetahui segala aspek yang terkandung di dalam obyek tersebut.

Jadi, deskriptif analisis merupakan suatu metode penelitian yang mengungkapkan tentang obyek dalam bentuk deskriptif yang disertai analisis terhadap segala sesuatu melalui pendekatan yang telah ditentukan. Dalam hal ini pendekatan etnomusikologis pendekatan ini tidak hanya terbatas pada musiknya akan tetapi mencakup seluruh aspek budaya yang ada kaitannya dengan musik (Nettl 1964:132)

Dalam penelitian ini, peneliti menggunakan teknik pengumpulan data, yakni (1) mengadakan pengamatan di lokasi penelitian, yaitu di Desa Tunjung Kecamatan Udanawu, Kabupaten Blitar, Provinsi Jawa Timur, (2) mengadakan perekaman data yang didapat dari informan, (3) mengadakan pencatatan yang berkaitan dengan kearifan lokal dalam seni Jemblung, dan (4) mengadakan wawancara dengan informan.

\section{HASIL PENELITIAN}

\section{Nilai Budaya Seni Jemblung.}

Berbicara tentang nilai budaya yang terkandung dalam seni Jemblung tidak terlepas dari karakteristik Islam dalam kesenian ini. Seperti yang terurai dalam bab pembahasan bentuk penyajian di atas, menunjukkan bahwa pada kesenian ini memiliki karater musik yang bernuansa Jawa Islam. Jika dianalisis pada bentuk penyajian pertunjukannya, kemasan dalam penyajian sudah menandakan bahwa kesenian ini bernuansa Islam. hal tersebut terlihat dalam berbagai aspek, yang pertama ; kostum yang dipakai dalang serta seluruh pemain yaitu baju muslim. Kemudian bahasa yang digunakan dalang dalam penyampaian makna doa serta kalimat-kalimat syiar maupun isinya menggunakan bahasa Arab. Misalnya pada pembukaan pertunjukan Jemblung selalu membacakan surat Al-Fatihah, serta menguraikan makna surat tersebut secara jelas.

Dilihat dari segi analisis penyajian sastra, pada teks nyanyian dan bahasa yang digunakan oleh dalang Jemblung adalah bahasa Jawa. Suatu misal dalam teks nyanyian lagu "mumpung urip sucinana badan sira", yang artinya selama masih hidup sucikanlah badan kita sendiri. Potongan teks lagu tersebut menunjukkan bahwa unsur bahasa Jawa masih mendominasi dalam kesenian ini.

Dalam pertunjukan seni Jemblung Murtadho selalu menyisipkan unsur nasehat atau uraian makna yang mengandung nilai-nilai sosial, pendidikan serta ajakan kepada masyarakat 
untuk belajar hidup sesuai norma-norma agama yang berlaku. Hal tersebut seperti yang terlampir dalam uraian pembahasan makna dan fungsi seni Jemblung Murtadho.

\section{Sebagai pembentuk mental masyarakat.}

Berkaitan dengan fungsi pendidikan di atas, kesenian ini mempunyai fungsi yang lain. Dalam kaitan ini para penonton pertunjukan seni Jemblung mempunyai latar belakang kehidupan yang berbeda-beda. Penyajian cerita lakon yang dibawakan oleh dalang Jemblung adalah mengandung unsur untuk membentuk mental masyarakat yang baik. Suatu misal membahas masalah narkoba dan perilaku menyimpang, maka bahan yang akan disajikan oleh dalang dimodifikasi secara improvisasi, sehingga arah cerita merujuk pada permasalahan yang terjadi dilingkungan sekitar pertunjukan. Dengan penjelasan serta mengacu pada kaidah dan norma agama, para penonton akan mengetahui mana yang baik dan buruk, serta mengubah daya pikir agar intropeksi pada diri sendiri.

Oleh sebab itu, pentingnya kesenian ini salah satunya adalah sebagai pembentuk mental masyarakat penikmat seni Jemblung Murtadho.

\section{Sebagai pengundang para pedagang untuk berjualan.}

Suatu pertunjukan seni tidak terlepas dari pelaku (pemain) dan masyarakat pendukung. Akan tetapi yang terlupakan adalah para pedagang yang selalu datang dalam pertunjukan seni Jemblung ini. Walaupun sifatnya hanya instan (sementara), namun peluang ini selalu diminati dan dimanafaatkan dengan baik bagi para pedagang. Tidak hanya pedang makanan, melainkan para penjual jasa mainan buat anakanak kecil. Hal tersebut sudah menjadi budi daya bagi masyarat desa maupun perkotaan, hanya saja produknya yang membedakan.

Melihat kembali permasalahan tersebut, maka peran pertunjukan seni Jemblung antara lain adalah menciptakan lahan jual instan bagi para pedagang dan penjual jasa mainan anak-anak.

\section{PEMBAHASAN}

Pertunjukan seni Jemblung Murtadho berbeda dengan kesenian lainnya yang ada di Jawa Timur, misalnya jaranan, kentrung, hadrah sholawatan, dan sejenisnya. Penyajiannya sangat kompleks, mengandung semua unsur. Pengolahan konsep oleh dalang Murtadho melengkapi kesenian ini lebih bermakna, mulai dari olah musik, nyanyian, cerita, dan amalan terkandung di dalam pertunjukan kesenian tersebut.

Seni Jemblung mengalami perkembangan sesuai dengan fungsi sosialnya dalam masyarakat. Sebelum berdirinya Jemblung Murtadho, kesenian ini sudah ada sejak nenek moyang. Akan tetapi walaupun berbeda mempunyai maksud dan tujuan yang sama-sama mengembangkan agama Islam. Perkembangan seni Jemblung mengalami pasang surut sesuai dengan situasi dan kondisi masyarakat setempat.

Dilihat dari bentuk penyajiannya, seni Jemblung Murtadho memberikan estetis dan nuansa yang sangat unik sekali. Kreatifitas 
pengolahan konsep penyajian membuat kesenian ini banyak diminati oleh masyarakat sampai sekarang. Konsep tradisi yang diolah dan dipadukan dengan unsur-unsur musik modern, membuat musik Jemblung lebih hidup dan variatif dalam penyajiannya. Dalam penyajian cerita, improvisasi humor yang dilakukan dalang Jemblung Murtadho juga sangat unik, hal tersebut yang membedakan dari dalang yang lain. Terlihat unik dan nyentrik pada pertunjukannya. Nuansa islami yang disajikan juga tidak monoton atau membosankan karena garapan musik, cerita serta komunikasi yang dilakukan oleh dalang Murtadho lebih memasyarakat, dengan kata lain mengikuti permintaan konsumen, akan tetapi tidak menghilangkan dan mengurangi keasliaan dalam penyajian musik tersebut.

Atas dasar konsep teori, data serta implikasinya, penulis menyimpulkan bahwa dalang Murtadho mempunyai karakteristik identitas yang kuat dalam seni Jemblung. Hal tersebut dapat dilihat dalam pertunjukannya, dalang Murtadho dapat mengomunikasikan pertunjukan Jemblung dengan masyarakat, dalang dengan pemain musik, serta dalang dengan penonton, sehingga membuat dalang Jemblung Murtadho berbeda dengan dalang Jemblung lainnya

Pertunjukan seni Jemblung menyajikan cerita Jawa Islam, mengandung muatan cerita perjalanan para Wali Songo. Salah satunya perjalanan Raden Said dalam membela kaum yang lemah sampai ia rela mendapatkan hukuman dari Adipati Wilwatika yang tak lain adalah ayah kandungnya sendiri. Tidak hanya sampai disitu saja, hukuman dari ayahnya tersambung dengan diperintahkannya putranya untuk pergi dari rumah, dengan maksud menimba ilmu agama dan mencari seorang guru, sebagai bukti bahwa pemikirannya selama ini benar. Melalui perjalanan yang panjang, dan akhirnya bertemu dengan Sunan Bonang, yang akhirnya mendapat gelar Sunan Kalijaga. Selain itu seni Jemblung juga mengambil cerita dari Babat Tanah Jawa.

Berdasarkan analisis instrumen, musik dalam seni Jemblung yang asli terilhami dari alat musik yang terbuat dari kayu dan kulit hewan. Hal tersebut menjadi inspirasi berpikir serta memiliki makna khusus bagi kehidupan sosial masyarakat desa seperti yang terurai dalam pembahasan. Instrumen asli tersebut berjumlah enam, di antaranya terbang, kentrung, kempling, kendang, kethuk, Jidor. Disisi lain, pertunjukan seni Jemblung mempunyai daya tarik tersendiri melalui unsur-unsur pendukung lain, diantaranya wayang kreatif sebagai simbol penokohan dari tokoh sebuah materi cerita yang disajikan, dan wujud dan rupanya berbeda dengan bentuk wayang secara umum.

Adapun makna dari hasil analisis instrumen dalam terbentuknya musik dalam seni Jemblung di atas adalah: instrumen terbang mempunyai makna dari kata "pinter" lan “imbang”, yaitu pintar dan seimbang, yang artinya dalam mencari ilmu harus seimbang, yang dimaksud ialah pintar dalam ilmu umumnya juga harus pintar ilmu agamanya, makna dari instrumen jidor bagi masyarakat Tunjung yaitu berasal dari kata "ben jo nyeje ben jo tledor" artinya 
supaya tidak menyendiri agar tidak salah jalan/telodor. Lebih jelasnya, menjadi orang itu jangan menyendiri atau menjauhkan diri sendiri, agar tidak dijauhi oleh masyarakat, dan jika ada sesuatu hal yang baru tidak ketinggalan, maka akan merugikan diri sendiri, instrumen kentrung mempunyai makna dari kata "diteken ben jluntrung”, yang artinya biar jelas jalan hidupnya, karena hidup kalau tidak jelas arah hidupnya maka akan mengalami hidup yang sesat, dan selama hidupnya akan hidup berantakan, sedangkan instrumen kempling tersebut mempunyai makna dari kata "ketun lek nekem ben panggah eling", yang artinya agama itu harus dipegang terus, agar manusia menjadi tahu mana yang baik dan buruk bagi kehidupan yang baik dan benar menurut syariah agama islam, instrumen kendhang makna kata "kanggo teken ben ora nendang-nendang”, yang artinya jika manusia sudah mendapatkan tongkat tiang agama yang benar, maka akan tahu tentang haram dan halal, supaya hidupnya kelak akan benar sesuai kaidah islam tidak terjerumus dalam kemaksiatan, adapun makna dari instrumen kethuk adalah diambil dari kata "Thuk" dalam arti Nuthuk (pukul secara terus-menerus sampai selesai). Dalam arti Jawa sampai tuthuk, yang artinya dalam belajar agama harus sampai selesai, jangan hanya sebagian-sebagain, nanti akhirnya akan menjadi "santri mbuki", yaitu santri yang tidak jelas tujuannya, dengan kata lain belajar agamanya hanya setengah-setengah, tidak serius,

Fungsi sosial seni Jemblung sangat kompleks, yaitu: (1) sebagai kepuasan estetis. Dengan memainkan musik Jemblung mereka merasa bisa memenuhi kebutuhan rohaninya akan keindahan. Unsur kesenangan dan kepuasan yang diperoleh pemain merupakan salah satu alasan yang mendasar; (2) sebagai hiburan. Pada aspek ini, sebagai hiburan merupakan salah satu fungsi dominan seni Jemblung; (3) sebagai sarana komunikasi, dalang murtadho mendesain kesenian ini menjadi sebuah hiburan yang komunikastif dengan penonton, mulai dari penyajian cerita maupun musiknya; (4) memperkuat penyesuaian dengan norma-norma sosial yang dimaksud adalah dalam bagian pertunjukan ini selalu menyampaikan tentang norma-norma yang berlaku dalam lingkungan masyarakat sekitar; (5) pengesahan institusi-institusi sosial dan ritual keagamaan, yang dimaksud adalah sebagai sarana ritual "ruwatan" yang biasa diselenggarakan oleh masyarakat yang mempercayainya; (6) sebagai sumbangan pada kelestarian dan stabilitas kebudayaan, adalah sebagai salah satu wujud upaya para seniman untuk tetap melestarikan budaya daerah peninggalan leluhur; (7) sebagai alat pendidikan (moral) bagi masyarakat. Dalam pertunjukan seni Jemblung selalu meyampaikan pesan moral yang baik kepada penonton, sebagai nilai edukatif kesenian tersebut; (8) sebagai pembentuk mental masyarakat. Tidak terlepas dari fungsi sebelumnya, bahwa dengan penyampaian nilai-nilai edukatif dapat membentuk mental masyarakat yang mempunyai arah positif; (9) sebagai sarana memperoleh penghasilan sampingan, adalah berkesenian Jemblung bukan tujuan utama dalam mencari 
penghasilan bagi para pemain. Namun paling tidak dapat membantu memenuhi kebutuhan yang tak terduga sebagai tambahan; dan (10) sebagai pengundang para pedagang untuk berjualan. Sesuai dengan data yang diperoleh penulis, menyatakan bahwa dengan adanya pertunjukan seni Jemblung, secara otomatis para pedagang datang untuk berjualan maupun menjual jasa mainan anak dengan bentuk yang lebih kecil jumlahnya.

\section{SIMPULAN}

Penelitian mengenai seni Jemblung dari aspek etnomusikologi yang meliputi bentuk musik, makna dan fungsi sosial, belum pernah dilaksanakan oleh peneliti lain, padahal dengan memahami hal-hal tersebut dapat membantu serta mengenal lebih jauh tentang seni Jemblung secara utuh. Pemahaman tentang seni pertunjukan rakyat sangatlah penting, hal tersebut membantu pelestarian budaya lokal yang mempunyai nilai-nilai budaya yang majemuk.

Kebudayaan lokal jenius merupakan aset budaya yang perlu dilestarikan. Seperti halnya seni Jemblung yang muncul dalam masyarakat desa, ternyata mempunyai bentuk kesenian yang berbeda dengan yang lain. Berbekal kaidah Islam dan keteguhan dalam tujuan syiar agama, kesenian ini mampu bertahan dengan segala keterbatasan apapun. Dimulai dari bentuk musik yang sederhana dengan konsep minimalis, seni Jemblung berkembang terus-menerus dan akhirnya diterima oleh khalayak ramai.
Atas dasar konsep teori, data serta implikasinya, penulis menyimpulkan bahwa dalang Murtadho mempunyai karakteristik identitas yang kuat dalam seni Jemblung. Hal tersebut dapat dilihat dalam pertunjukannya, dalang Murtadho dapat mengomunikasikan pertunjukan Jemblung dengan masyarakat, dalang dengan pemain musik, serta dalang dengan penonton, sehingga membuat dalang Jemblung Murtadho berbeda dengan dalang Jemblung lainnya.

Dari beberapa fungsi di atas, dapat dirumuskan bahwa dalam sebuah seni Jemblung terdapat fungsi sosial bagi masyarakat, yang pada intinya kesenian ini dapat digunakan sebagai sarana dalam menyampaikan sebuah pesan edukatif bagi masyarakat yang lebih baik.

\section{DAFTAR PUSTAKA}

Barker, C.

2005. Cultural Studies (Teori dan Praktik). Yogyakarta: PT Bentang Pustaka

Denzin, N.K, L. Yvonna S (Eds).

2009. Handbook of Qualitative Research. Yogyakarta: Pustaka Pelajar

Hood, M.

1982. The Ethnomusikologist. New York, McGraw-Hill: The Kents State University Press

Haviland, W.

1975. Cultural Antropology. New York: Holt, Rinehart and Wiston,Inc

Kunst, J.

1994. Indonesian music and dance. Amsterdam: University of Amsterdam/ Ethnomusicology Center 'Jaap Kunst'

Merriam, A.P. 
1964. The Anthropology of Music. Chicago: North Western University Press

Nakagawa, S. Prof.

2000. Musike dan Kosmos: Sebuah Pengantar Etnomusikologi. Jakarta: Yayasan Obor Indonesia

Nettl, B.

1984. Theory and Method in Ethnomusikology. London: The Free Press of GlencoeMacmillan Limited

Winfried, $\mathrm{N}$.

1990. Handbook of Semiotics. USA: The Association of American University Presses 